\title{
ARCHITECTURAL HERITAGE BUILDING IN THE STATE OF SÃO PAULO: SURVEY AND DIGITAL DOCUMENTATION OF A JESUIT MISSION
}

\author{
S. Bertocci ${ }^{1, *}$, M. Bigongiari ${ }^{1}$, P. Becherini ${ }^{1}$, A. Cottini ${ }^{1}$ \\ ${ }^{1}$ Department of Architecture - University of Florence, Italy - (stefano.bertocci, matteo.bigongiari, pietro.becherini, \\ anastasia.cottini)@unifi.it
}

Commission II - WG II/8

KEYWORDS: Brazil, Mission, Vernacular architecture, Documentation, Digital survey, UAV

\begin{abstract}
:
This paper describes the digital survey activities carried out in Brazil, in the state of São Paulo, in order to document historical architectures and his vernacular features. After introducing the researches performed in Brazil in the last years, the Brazilian state-of-art of architecture is summarised, so that it is possible to understand the complexities and the referential typological and cultural models. Typical Paulistano vernacular building techniques are thereafter deepened, before outlining the case-study of the Jesuit mission of Carapicuiba, one of the few rammed earths building in existence in São Paulo. Quick digital survey techniques, like aerial photogrammetry, make possible for architects and scholars to rapidly record the building's morphology and state of preservation, for future cultural heritage conservation. Research findings permitted to update the settlement's survey data, specifically the ones linked to surfaces, colors, and materials.
\end{abstract}

\section{INTRODUCTION}

In September 2017 a cooperation was started between the Department of Architecture - the University of Florence and the Faculdade de Arquitetura e Urbanismo - University of São Paulo, in order to apply to the Brazilian case, the architectural survey methodology already experienced in Italy - focusing on the latest developed digital technologies. The interest in expertise exchanging between students and researchers coming from different countries led to repeat this experience every year in the last three years, with an intensive three-weeks digital survey workshop during the Brazilian degree course. The workshop lessons were articulated in two parts: the first one with lectures about theoretical principles of the morphological survey, the second one with practical application on some typical São Paulo buildings ${ }^{1}$. The survey on-site practical applications have made it possible for the researchers of the University of Florence to deal with a built environment which is different from the European one and is motley both for typology and style ${ }^{2}$. The strong economic, demographic and urban development faced by São Paulo in the last centuries caused the loss of a large portion of the historical buildings and heritage, because of an urban planning policy that was not conservation-minded towards assets of cultural heritage interest ${ }^{3}$. Therefore, during the field experience, it was possible to deal with modern buildings, such as skyscrapers and Paulista school brutalist structures, but also with historical buildings, both religious and civic, that feature traditional ornamental and building techniques. It is important to notice that these historical buildings do not go back before colonial times (1500), still they are traditional and have on the inside some rammed earth wall portions, built by means of the local vernacular techniques. One of the examples in São Paulo is the Solar da Marquesa de Santos ${ }^{4}$, one of the oldest building of the city which is also part of the Museu da Cidade, where some parts of the rammed earth walls are left exposed without any plastering. Studying historical architectures that belong to cultural heritage made it possible to analyze a large variety of buildings in different contexts and to understand the significant developments of Brazilian architecture, both religious and civic, from the first settlements to the major metropolitan areas, from the reducciones to the big religious complexes (Figure 1).

This paper shows how digital survey techniques are a useful and necessary tool to document and preserve cultural heritage, giving the example of a case study.

\section{DISCUSSION}

\subsection{Historical and architectural notes}

The vast Brazilian architectural historiography ${ }^{5}$, since the postWorld War II era, follows two different interpretative models: the first one is linked to a Eurocentric approach and considers colonial manufacturing as a direct consequence of the European one, the second one is related to anthropological and sociological aspects, aiming at identifying an original and autonomous cultural and artistic expression of the local populations (Bonamico, Cacciavillani, 2000).

\footnotetext{
Corresponding author

1 The first results were introduced in the publication "Uid Symposium on the internationalization of research", (Bertocci, Conte, 2019) pp. 58-63.

2 Some of the heritage documentation experiences has already been published (Becherini, Bercigli, 2018).

3 In the UID 2019 congress a first experience of documenting the building heritage of San Paolo has been presented (Cottini, 2019).
}

4 A digital survey campaign was carried out inside this building in September 2019

5 The studies on colonial architecture in the northeast of Brazil are part of a vast bibliography (Spesso, 2010). From the end of the 16th century, the works written by the diarists show an awareness of the formation of a strong Brazilian identity, which was still linked to Portuguese traditions, but was starting to express peculiarities of the colony's territory. 

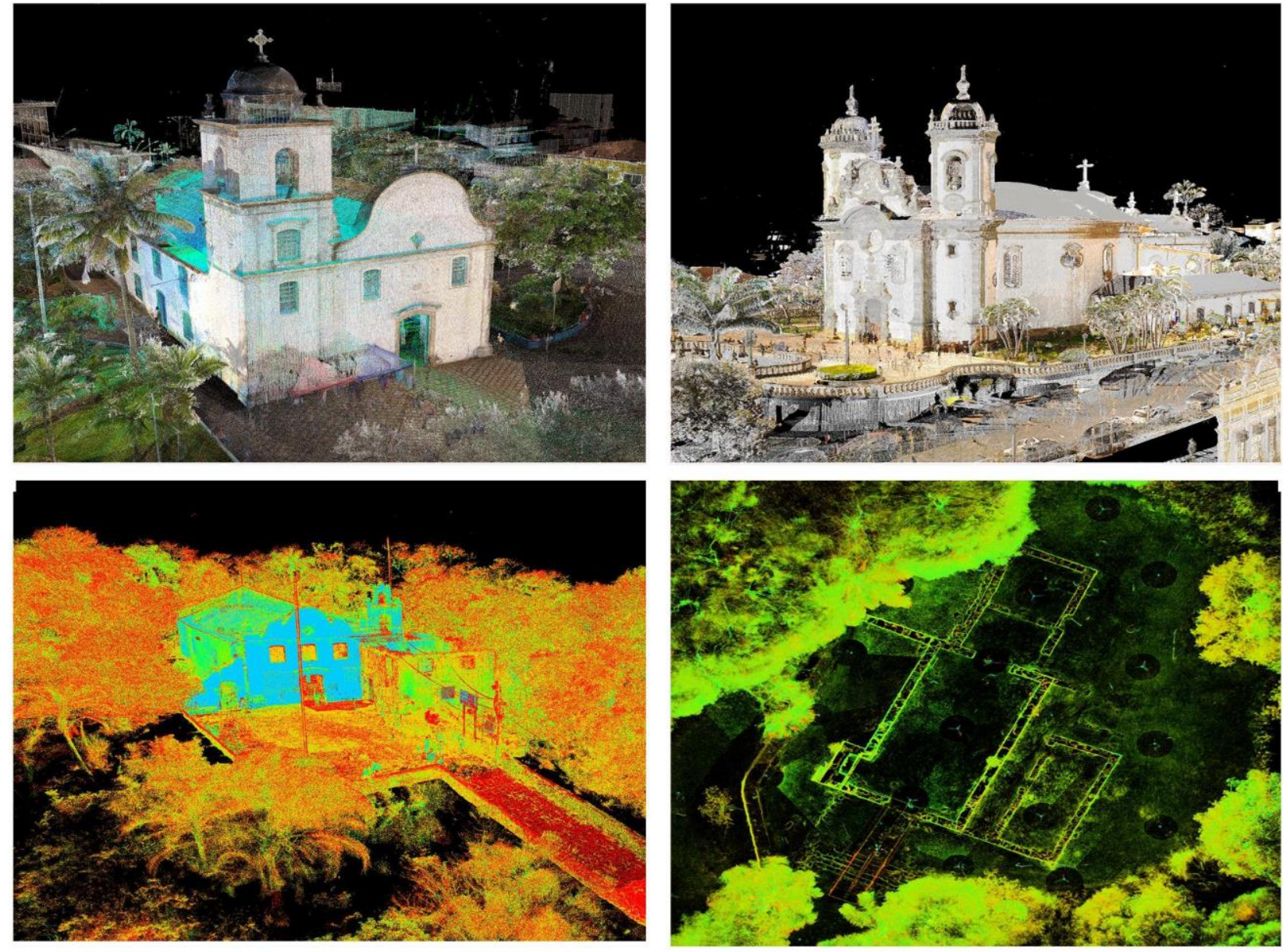

Figure 1. Laser scanner point clouds obtained during the Brasilian experiences (2017-2019): (top-right, clockwise) Igreja Matriz de Sant'Anna, Itanhaem, Church of San Francesco di Assisi in São João del Rei, Convent Nossa Senhora da Conceição, Itanhaem,

Ruins of Abarebebe, Peruibe.

In Brazil, there is no scientific interest towards the native history of art and architecture before 1950 (Bazin, 1955), so that many cultural heritage artefacts had gone missing in the XX century process of new urbanisation. Studies related to Brazilian cultural heritage and to religious buildings pointed out how Brazilian models - especially the baroque ones - do not strictly follow European formal rules, but they develop as a Latino adaptation to the cultural movement of the time, in different ways depending on the local populations (Sebastian, 1990). The first postcolonization (1500) architectural and urban developments in Brazil belong to two categories: on one hand the civic buildings promoted by the royal administrative bodies, with the employment of military engineers and craftsmen, on the other hand, the religious orders buildings, with artistic and technical expertise that comes from the local artisans' knowledge. Usually, members of Jesuit, Franciscan, Carmelite, Benedictine or Augustinian religious orders took part to the naval expeditions funded by the Portuguese crown, given that the search for new trade routes was strictly connected with the evangelizing missions ${ }^{6}$. From an urban point of view, monastic settlements followed a pattern which was different from the one followed by the first residential settlements: the first ones were planned accordingly to a specific rule, the second ones were born in a spontaneous, less controlled way, depending on the local features, possibly having defensive needs (similarly to the Lusitanian perched towns). Originally, the Jesuit one was the most influential order, promoting a widespread diffusion of settlements and importing in Brazil some of the leading personalities in architecture, like Francesco Dias, whose rigorous modus operandi became an essential reference also for the other religious orders ${ }^{7}$. Their relationship with the royal authority, however, was different from the other orders' one: by pledging allegiance to the Pope, they developed a missionary policy oriented towards a greater autonomy from the monarchy, until in 1760 a royal decree was pronounced to expel the Jesuit order from Brazil (Leite, 1938).
6 This was part of the Patronage system, a privilege granted by the popes to the kings of Portugal thanks to the Reconquista: complete control was exercised on the missions and on the bishops themselves, also providing for the expenses for religion, including those for the construction of the buildings.
The "modo nostro" refers to the norm, to the modus operandi and not to the artistic modality, and therefore to the organizational problems of the building and the construction site. The values of austerity, severity and rigor were the cornerstones of their "widespread planning", not unified but flexible, depending on the specific needs of each place. 

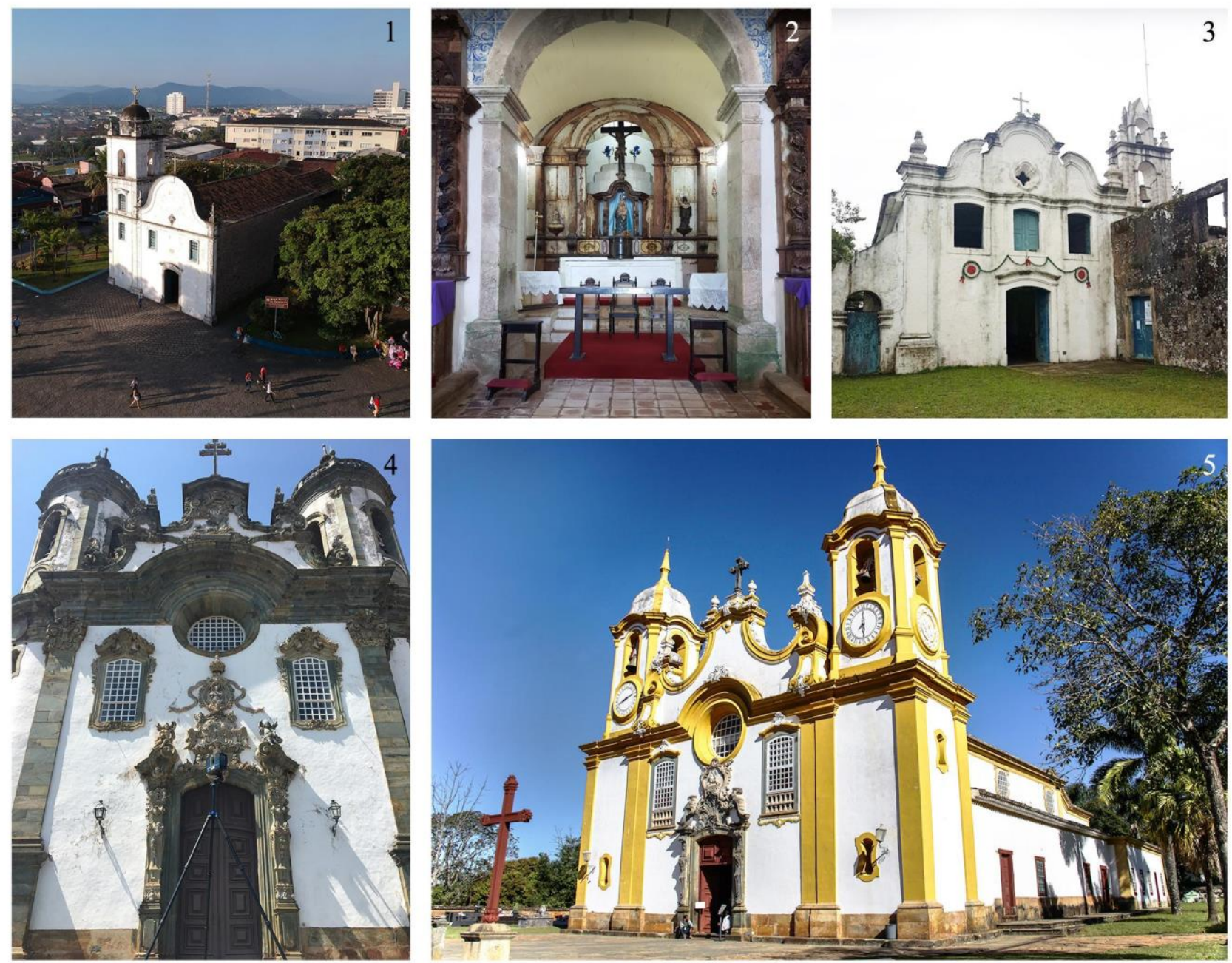

Figure 2. Examples of Heritage colonial religious Building: (clockwise) Sant'Anna Church, the interior and exterior of the Convent of Nossa Senhora in Itanhaem, the facade of San Francesco d'Assisi in Sao Joao del Rei and Igreja Matriz de Santo Antonio in Tirandentes.

The Franciscan order was also widely spread in the Brazilian territories and, from an architectural point of view, they promoted some traditional medieval Portuguese elements, such as the tripartite narthex (galité) or the tetrastyle portico (alpendre). The Carmelite, Benedictine and Augustinian orders actively participated in the evangelization of the Lusitanian colonies. After Portugal reconquered his autonomy from the Spanish monarchy (1640), the colonies began to perceive the loosening of the rigor in the fields of art and architecture, as a consequence of the Council of Trent, and the orders started to experiment more, although maintaining traditional construction techniques and typological choices.

It is legitimate to say that Brazilian architecture is strictly linked to the typical Lusitanian construction types and decorative apparatus, in particular in religious, administrative and wealthy landowners' buildings, however, it is necessary to study this architecture from a slightly different point of view, trying to analyze the components that stand apart from the European models and get mixed up with the vernacular features. These vernacular features come both from indigenous culture and African slaves imported in Brazil. For instance, changes in everyday life between Old and New World also affect architecture, especially regarding homes indoor distribution; in a similar way, the religious buildings' decorative apparatus switches from traditional portrayals to depictions of natural elements (Figure 2).

The formal features of Baroque architecture and art, which have precise spatial needs and shape the urban space as in a system of interconnected focal points (Norberg Schulz, 1979), can be found also in the first Brazilian religious settlements, although there are some differences due to the vastness of the territory and to the absence of ties with any previous building (Bastide, 1971).

Therefore, in order to facilitate the conversion of indigenous and African peoples and to align with the Baroque style, the typical religious missions are born, mostly thanks to the Jesuit order. The characteristic layout includes a big square aligned with the religious building and with facilities around it.

The formal link between historical Brazilian architecture and the Lusitanian one is indissoluble because the structures depend strongly on the availability of materials found in construction sites and request simple solutions: thatched roof, taipa or adobe walls - and only afterward stone and lime masonry.

New settlements are always funded in connection with a sacred context: along with a new community, a place of worship rises, often built by indigenous people to whom the European building techniques were taught. 

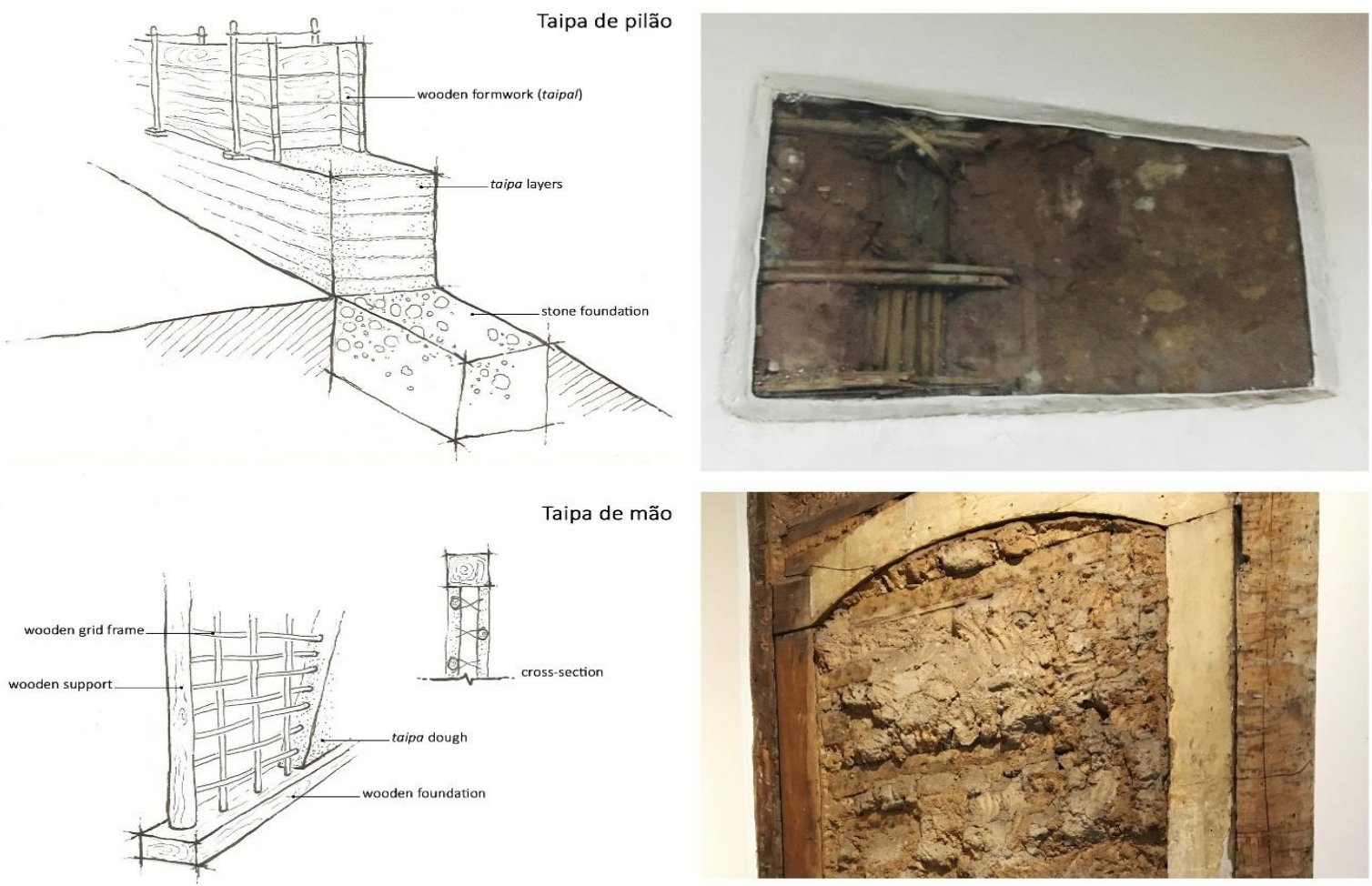

Figure 3. (Right) Constructive drawings of the two main masonry detail: taipa de pilao and taipa de mao; (left) two example of taipa masonry that can be seen in San Paolo city, on the top Igreja de Santo Antônio, lower the Solar da Marquesa building.

\subsection{Vernacular building techniques}

Brazilian colonial architectures, specifically the ones built by mestizo communities that included indigenous and African people, show technical features that are strongly linked to precolonial buildings. These buildings exploited the abundance of wood and clay that the Brazilian land offers and featured rammed earth, straw and mud structural elements. Earthen buildings, therefore, are attested in Brazil since colonial times (1500), given that Portuguese settlers, imported slaves from Africa and local tribes already employed taip ${ }^{8}$ techniques (Justi Pisani, 2004). It is possible to say that there is a strong relationship between vernacular technology and local culture and society, especially in the complex Brazilian context, featuring a mix of different traditions - indigenous, Portuguese, Spanish, Dutch, French, African, Japanese, Italian (Rezende, Leite, Cardoso, 2014). (Figure 3) Taipa buildings have certain advantages and disadvantages that are peculiar to the material itself, such as the benefits in energy efficiency and recyclability, or the downsides in permeability and cracking. Moreover, it is not possible to have an exact composition for this material, because it depends on the geological and climatic characteristics of the extraction site - this means that its mechanical resistance, texture, and performance may vary. The two main typologies of taipa are de pilão and de mão. The first one is named after the pilão, or masher, used to press the earth inside the wooden formwork called taipal. Clay is chosen by following visual and tactile criteria, and must be free from sand, gravel and other organic materials; the dough is prepared by crumbling the clay and spraying it with water, obtaining an even mixture. Sand,

8 Or rammed earth, is a technique for constructing foundations, floors and walls using natural raw materials such as earth, chalk, lime or gravel. lime, vegetable fiber or manure can be added to the mixture before the setting up. The dough is cast into incremental layers by means of the taipal until reaching the requested height. After the walls dry out, in three to six months, the coating can be applied - its material changes depending on the location of the building and can be tabating $a^{9}$, mortars, manure or vegetable fiber. The main issue with this kind of building is its vulnerability to humidity and rain, thus it needs to be built on higher ground and be provided with drainpipes.

Taipa de mão has qualities that are similar to the pilão's ones but is based on a wooden grid frame, a cage that works as an independent structure, on which the dough is manually placed. This kind of taipa is usually employed for internal walls because of its lightweight and fast-drying (Justi Pisani, 2004).

Taipa de pilão was widely employed in the Paulista architecture from 1500 to 1850, when a public campaign was created in order to avoid taipa buildings, mainly because of the frequent floods, but it was still used until 1940 (Schmidt, 1946). Nowadays, taipa buildings in Brazil are attested in the North-eastern and Northern regions, along with other earth construction techniques such as adobe ${ }^{10}$. From the first half of the twentieth century, indeed, in São Paulo bricks and reinforced concrete are rather used for the new buildings that replace the colonial ones. This results in the almost absence of taipa buildings: among the ones that are left there are the village of Carapicuiba and the Solar da Marquesa (documented by means of a digital survey) and a musealised wall inside of the Patio do Colegio.

9 A clayey compound formed from a unique mixture of rare materials found on the bottom of ponds or rivers.

${ }^{10}$ An adobe brick is a composite material made of earth mixed with water and organic material such as straw or dung 

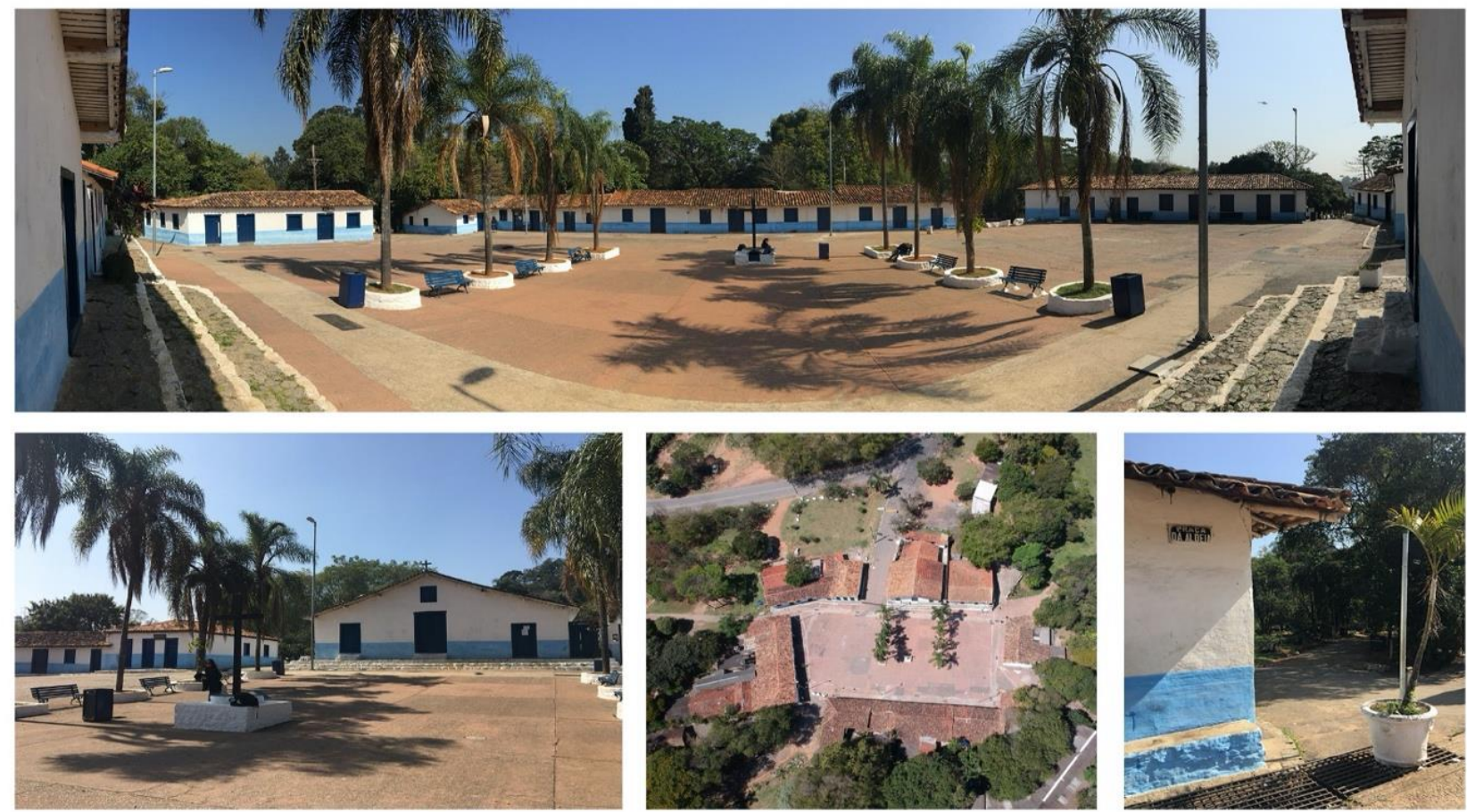

Figure 4. Overview and views of the village of Carapicuiba.

It is interesting to note that in São Paulo society and housing paradigm are strictly connected (Frehse, 2000), starting from casa bandeirista $^{11}$, the first evidence of taipa utilization and linked to Portuguese and mamluk research expeditions. Then there is a progressive introduction of brick constructions, whilst maintaining a traditional housing layout, during the economic changes that occurred in the second half of ' 800 - to eventually arrive at the late ' 800 architectural eclecticism, that replaces rammed earth technology and is indicative of a society that aims at everyday habits and commercial activities renewing (Frehse, 2000).

\subsection{Case-study: the village of Carapicuíba}

Carapicuíba is one of the twelve countries founded by the Jesuit friar P. José de Anchieta ${ }^{12}$ at the end of the 16th century, with the aim of providing for the formation ${ }^{13}$ and evangelization of the Guaianases ${ }^{14}$, starting the process that led to making the tribe indigenous sedentary. It is located in the state of São Paulo, 20 $\mathrm{km}$ from the center of the capital, and occurred after the construction of the tracks of the Sorocabana railway in 1875 Today it represents one of the most recent examples of its kind nearby in the $\operatorname{are}^{15}$ and is characterized by the typical composition of the mission villages, where the popular religious and folkloristic traditions are preserved, which is why in 1940 it was included in the register of the IPHAN ${ }^{16}$ (Pellegrini, 1979; Barroca Faccio, 2000; Pereira, 2014) (Figure 4).

The site is also part of the Taypa de Pilão circuit ${ }^{17}$, since it is an example of a missionary complex that survived the modernization of buildings and has preserved its patrimonial, architectural and cultural characteristics, typical of the indigenous and Jesuit coexistence in the colonial period. The composition scheme of the village is of the hippodameo type, preferred by the Jesuits ${ }^{18}$.

11 The Bandeirantes were 17th-century São Paulo inhabitants and Portuguese settlers in Brazil and fortune hunters.

12 Jesuit, linguist and Spanish missionary, considered by the cities of São Paulo and Rio de Janeiro among their founders and the father of Brazilian literature, between 1980 and 2014, he was proclaimed first blessed and then holy with the equivalent canonization.

13 According to Francisco de Assis Carvalho Franco, quoted by the architect C. Lemos (Lemos et al, 2008), Carapicuíba was never a real village created by the Jesuits to confine the índios converts. In reality, it was born as a deposit for the Indians driven out by the sertainist Afonso Sardinha.

14 The Guaianás Indians were a South American indigenous group that populated the regions between San Paolo di Piratininga and Uruguay until the end of the 16th century.

15 It is considered an architectural and historical landmark of the political-metropolitan region of São Paulo (RMSP) because of the permanence of its original characteristics.

16 The Instituto do Patrimônio Histórico e Artístico Nacional is a register of assets of the federal government of Brazil, responsible for the conservation of buildings, monuments, structures, objects and sites believed to be of historical or cultural importance for the country.

17 The Taypa de Pilao Circuit consists of assets registered by the IPHAN, from the colonization period of the western surroundings of the metropolitan area of the state of Sao Paulo, between the 16th and 19 th centuries.

18 The rectangular-based villages were oriented in space, far from the large rivers, but close to its tributaries, the arrangement of the houses with the church that was always in the middle, on the highest side of the slope. The streets also usually graft into the square at the relative corners of the courtyard. These villages were always in high areas, from where it was possible to dominate the surroundings. 

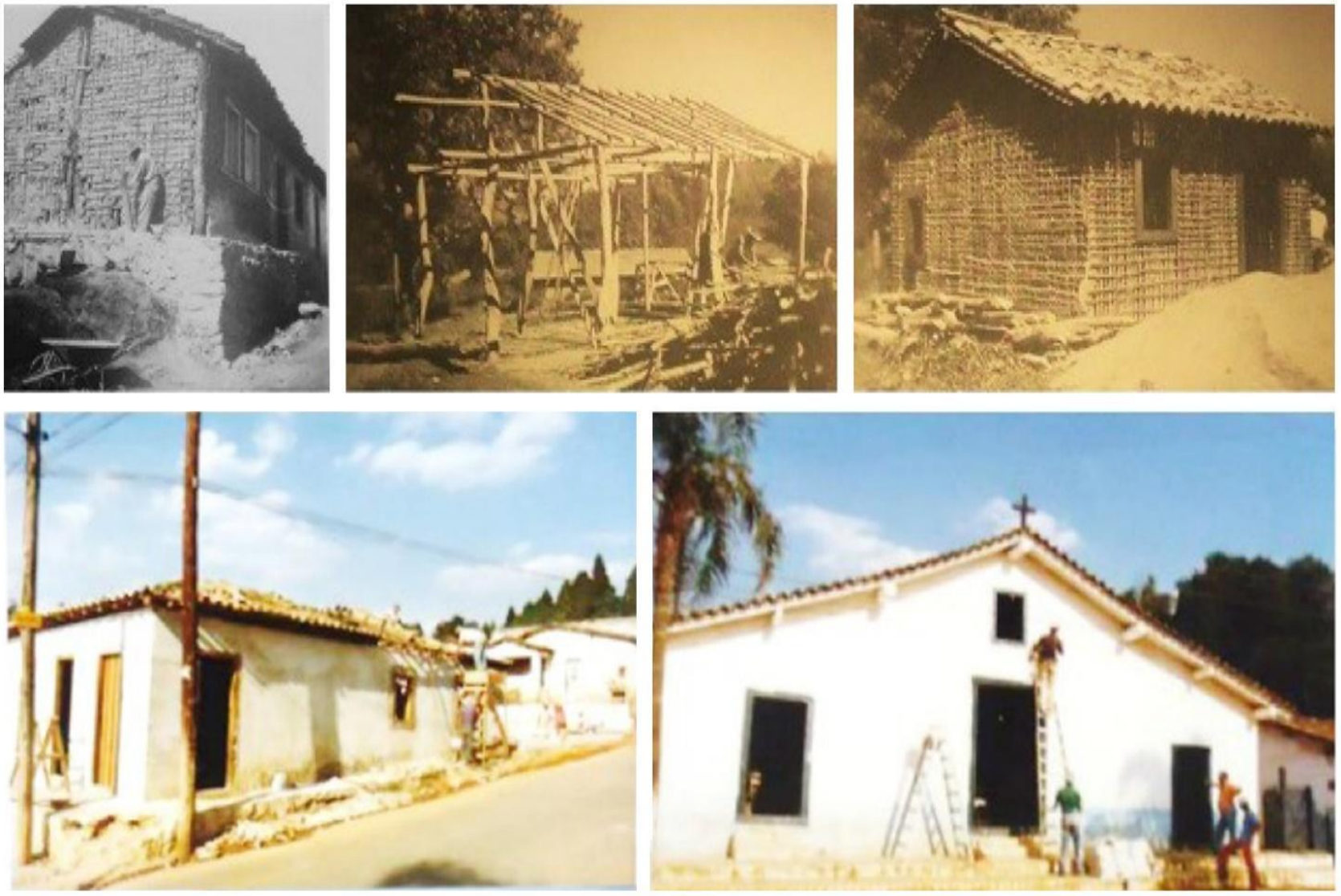

Figure 5. Different stages of renovation of the Apericube Village.

The site is developed around a rectangular square, overlooked by small gabled roofs terraced houses made of mud, with the taipa technique. In its center, a large area was left free ${ }^{19}$ in front of the Catholic church, which represented the most significant construction of the urban landscape, with two rows of palm trees forming a churchyard and a cross placed on a brick pedestal.

The church of the village of Carapicuíba was built in 1736, after that the previous chapel, which was dedicated to Saint Catherine of Alexandria, was destroyed ${ }^{20}$. In the first decades of the twentieth-century important restoration works of the site are documented, unfortunately without an adequate maintenance and enhancement plan; only since 1984 more adequate instruments have been adopted for planning and maintaining buildings (Figure 5).

With the municipal law 714/84, the intent was made official for the protection and safeguard of the national historical heritage through structural and urban improvements to the site. In 2008, due to conditions of advanced degradation and modification of the intended use of some buildings in the village, an inspection was carried out, aiming at verifying the state of conservation of the site and identifying any sign of degradation and distribution changes through photographic campaigns. At the same time, an analysis of the urban surroundings was carried out to highlight

19 The layout of the houses with a free area in the centre is universal, according to what was written by former president IPHAN Luis Saia, (Saia, 1937): the residential quadrilateral for "families" with one side occupied by the temple and the friars' houses.

20 In 1698, the Jesuits destroyed the village of Carapicuíba, rebuilt in the same place in 1736 , on the basis of the three walls of taipa left of how the village is currently inserted within a wooded park, which is starting to be approached by the rapid expansion of the vast residential and industrial neighborhoods that threatens the conservation of the Carapicuíba landscape.

The digital survey presented below is part of this scenario and is configured as an important cognitive phase to produce a database of morphological and qualitative information useful for the overtime management and documentation of the village and its patrimonial value.

The creation and processing of a 3D model will allow the current appearance of the village to be archived as historical documentation for future analysis; the creation of a digital database will also be useful to enhance and promote the site. The area of the village was first analyzed through the testing of photogrammetric survey methodologies, exploiting the potential of drone acquisitions, thus deepening the management of the RPAS system ${ }^{21}$.

The characteristics of the drone made it easy to maneuver, thanks also to the lack of obstacles, considering the high trunk vegetation in the central part of the square to be irrelevant, ensuring a safe and precise flight with the acquisition of photographic and video material of the buildings.

the old chapel of São João Batista, which was later called the chapel of Nossa Senhora da Graça.

21 The abbreviation RPAS stands for Remote Piloted Aircraft System. A set of elements such as drone, radio, pilot, ground station and everything necessary for the operation, in this case, of photogrammetric importance 


\subsection{Photogrammetric survey}

The vertical images were acquired with a SPARK model drone, produced by DJI ${ }^{22}$. Equipped with a camera with sensor size 3968 $\times 2976$ pixels and with $1 / 2.3$ "CMOS sensor, f / 2.6 lens, with an equivalent focal length of $25 \mathrm{~mm}$. Through this acquisition, the mapping of the village area was produced and subsequently, it was taken a shot of all the fronts of the buildings facing the square. The campaign was carried out with a continuous shutter mode $^{23}$ to obtain a faster acquisition of the images, while keeping the focus on the selected element via the touchscreen of the smartphone connected to the remote control of the acquisition process, following a "serpentine" trend to obtain continuous data of the analysed object. The acquired images were approximately 350 , from an average flight altitude of $30 / 40$ meters and with a relative overlapping of $80 \%$. The optical images, obtained from the photographic campaign images, were processed using the Reality Capture 1.0.5 software, based on the SfM algorithm which allows digital reconstruction of the $3 \mathrm{D}$ model of the entire survey area, from the 350 aerial images (Figure 6) The import and image processing parameters were left at the default values to make the procedure as standardized and comparable as possible. This work, carried out for the first time in the municipal area of Carapicuíba, led to obtaining the technical drawings mapped with textures, in particular the plan and the elevation of the buildings overlooking the square, allowing to compare the drawings with the previous 2008 survey, adding textural information, which is important to analyze the building's facades and to verify the state of conservation of the surfaces (Figure 7).

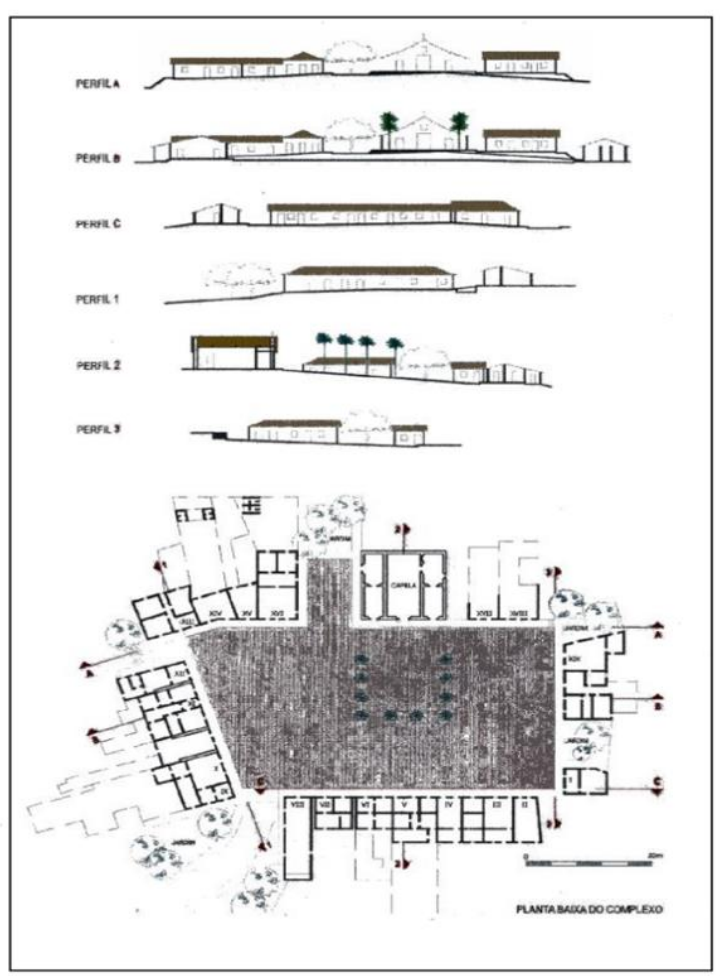

Figure 7. Floor Plan of the Carapicuíba Complex. Source: Lemos et al., 2008, p. 95.
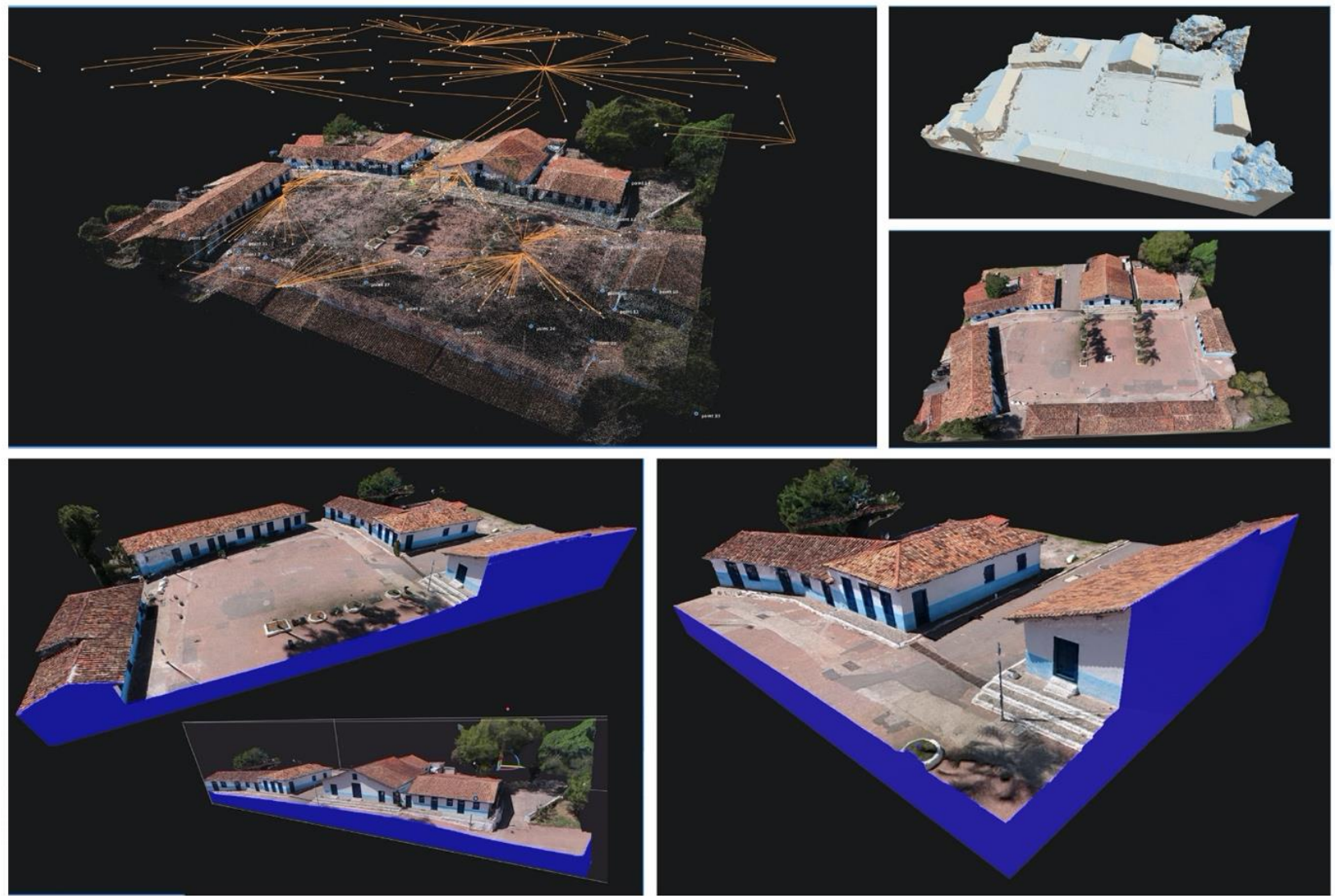

Figure 6. Views of the images processing, of the model and texture reconstruction, and of the extractions of section from the 3Dmodel, obtained with the Software @ Reality Capture.

\footnotetext{
22 The reference refers to the date of use of the drone. September 2019
}

23 With this multiple mode you can quickly capture several photos. You can set a variable number of shots with a single touch 3,5 or 7 photos 


\section{CONCLUSIONS}

The paper deals with the architectural and technical characteristics of the Brazilian vernacular architecture of the state of Sao Paulo, highlighting the causes that led to the rapid loss of most of these buildings in the last century; by erasing the traces of the characteristic architecture of the early colonial periods of Brazil, the population risks forgetting its history and values. The contribution provided by the digital survey lies precisely in memory: in creating the digital documentation of those structures, of those buildings with historical and patrimonial interest to crystallize the image of these architectures over time, making them accessible to the community. Beyond that, the technical qualities and the geometric and color reliability of the drawings, that can be obtained from the three-dimensional models, are useful tools for the administrations: they can be provided for the conservation of the heritage and its image, as in the case of the village Jesuit of Carapicuiba (Figure 8).

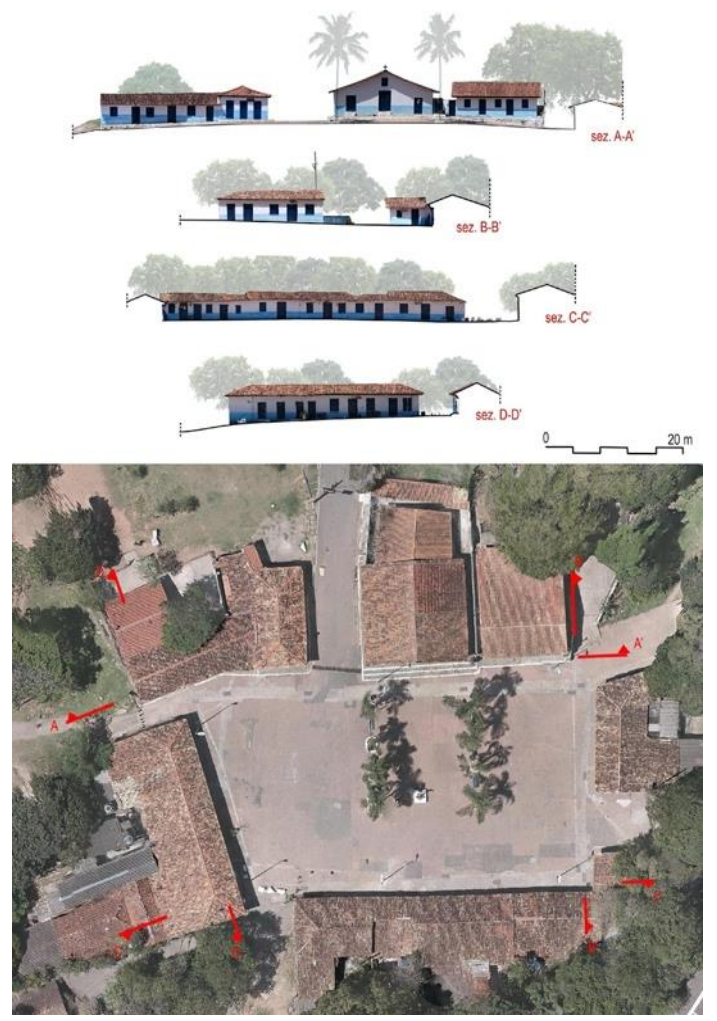

Figure 8. Final Drawings obtained from Unmanned Aerial Photogrammetric Survey: it was possible to add the photographic information to the CAD lines.

\section{ACKNOWLEDGMENTS}

The project presented in this paper stems from the interest in Brazilian colonial and vernacular architecture and studies developed by professors Luciano Migliaccio and Renata Martins, that we want to thank. The iconographic material of the digital surveys was created by the UNIFI working group. The iconographic material of the digital surveys was created by the UNIFI working group, responsible for prof. S Bertocci, tutors, Bigongiari, Cottini, Becherini; partly during the LabSampa course, as part of the master's degree course coordinated by prof. Luciano Migliaccio and Beatriz Bueno, with the support of Regina Helena Santos and Rodrigo Gutierrez; the issues related to the digital survey were developed with lectures and practices carried out by the writers. This paper, which was born from a common research and documentation work of the writers, was written with the following credits: Stefano Bertocci wrote the Introduction paragraph; Matteo Bigongiari wrote Historical and architectural notes; Anastasia Cottini wrote Vernacular building techniques, Pietro Becherini wrote Case study: the village of Carapicuiba, and Photogrammetric survey.

\section{REFERENCES}

Barroca Faccio N., 2010, A Aldeia Carapicuiba e sua resolucao de tombamento, São Paulo.

Bain, G., 1955, L'architecture Religieuse Baroque au Bresil, Museu De Arte/ Librairie Plon, São Paulo/ Paris.

Bastide, R., 1971, Brasil terra de contrastes, São Paulo.

Becherini P., Bercigli M., 2018, Il rilievo integrato per la conoscenza e la valorizzazione. I casi studio del convento di Itanhaem e delle rovine di Abarebebe sulla costa paulista (San Paolo, Brasile), $\mathrm{VI}^{\circ}$ International Congress, ReUSO Messina, pp.105-116.

Bertocci, S., Conte, A., 2019, Il Simposio UID di internazionalizzazione della ricerca Didapress, Firenze.

Bonamico, S., Cacciavillani, C., 2000, Brasile ieri, Gangemi, Roma.

Cottini, A., 2019, Il disegno dei fronti urbani dell'Avenida São João nel centro storico di São Paulo in Brasile, $41^{\circ}$ Convegno Internazionale dei Docenti delle Discipline della Rappresentazione RIFLESSIONI REFLECTIONS l'arte del disegno / il disegno dell'arte the $\mid$ art of drawing / the drawing of art Perugia | 19-20-21 settembre 2019.

Frehse, F., 2000, Carlos A. C. Lemos. Casa paulista: história das moradias anteriores.

Justi Pisani, M.A., 2004, Taipas: a arquitetura de terra, Sinergia, São Paulo, v. 5, n. 1, p. 09-15, jan/jun. 2004.

Leite S., 1938-1950, Historia da Companhia de Jesus no Brasil, Lisboa, Portugalia, 10 voll.

Lemos, Carlos Alberto Cerqueira; MORI, Victor Hugo; Alambert, Clara Correia d'. Antiga Aldeia de Carapicuíba. In: Patrimônio 70 Anos. Org. Marisa Campos de Souza e Rossano Lopes Bastos. São Paulo: 90 SR/IPHAN, 2008.

Norberg-Schulz, C., 1979, Architettura Barocca, edizione italiana, Milano.

Pellegrini A., 1979, Aldeia de Carapicuíba: folclore e mudanças. Dissertação (Mestrado em Artes). Escola de Artes - ECA/USP, São Paulo.

Pereira P.C.X., 2014, Aldeamento indígena colonial e Aldeia Global fragmentada: uma discussão sobre espaço e poder em São Paulo.

Rezende, M.A.P., Leite J.L.R., Cardoso, F.M.P., 2014, Vernacular technology in Brazil: Transformation and preservation.

Saia L., 1937, Aldeia de Carapicuíba, São Paulo, IPHAN.

Sebastian, S., 1990, L'arte barocca in America Latina, edizione italiana, Milano.

Spesso, M., 2010, Rotte atlantiche dell'architettura italiana. Il nordeste al tempo dell'egemonia dello zucchero brasiliano (15491676), ETS, Pisa. 